\title{
A common garden experiment examining light use efficiency and heat sum to explain growth differences in native and exotic Pinus taeda
}

\author{
Timothy J. Albaugh ${ }^{\mathrm{a}, *}$, Thomas R. Fox ${ }^{\mathrm{b}}$, Chris A. Maier ${ }^{\mathrm{c}}$, Otávio C. Campoe ${ }^{\mathrm{d}}$, Rafael A. Rubilar \\ Rachel L. Cook ${ }^{f}$, Jay E. Raymond ${ }^{\mathrm{a}}$, Clayton A. Alvares ${ }^{g}$, Jose L. Stape ${ }^{\mathrm{h}, \mathrm{i}}$ \\ ${ }^{a}$ Virginia Tech, Department of Forest Resources and Environmental Conservation, 228 Cheatham Hall, Blacksburg, VA 24061, USA \\ ${ }^{\mathrm{b}}$ Forest Productivity and Sustainability, Forest Research Center, Rayonier Inc., Yulee, FL 32097, USA \\ ${ }^{c}$ USDA Forest Service, 3041 Cornwallis Road, Research Triangle Park, NC, USA \\ ${ }^{\mathrm{d}}$ Federal University of Santa Catarina, Curitibanos, SC, Brazil \\ e Cooperativa de Productividad Forestal, Facultad de Ciencias Forestales, Universidad de Concepción, Victoria 631, Casilla 160-C, Concepción, Chile \\ ${ }^{\mathrm{f}}$ Department of Forestry and Environmental Resources, North Carolina State University, Raleigh, NC 27695-8008, USA \\ ${ }^{\mathrm{g}}$ Forestry Science and Research Institute - IPEF, Piracicaba, SP 13400-970, Brazil \\ h Department of Forest Science, Sao Paulo State University and Botucatu, SP, Brazil

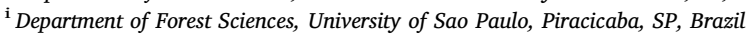

\section{A R T I C L E I N F O}

\section{Keywords:}

Absorbed light

Density

Genotype

Natural range

Vapor pressure deficit

\begin{abstract}
A B S T R A C T
Previous work indicates that Pinus taeda L. grows faster and has a higher carrying capacity when grown outside its native range. We were interested in examining the hypotheses that growth, light use efficiency (volume growth and absorbed photosynthetically active radiation relationship, LUE) and volume growth per unit heat sum is the same for native and exotic plantations. To test these hypotheses, we installed a common garden experiment where the same six genetic entries of $P$. taeda (four clonal varieties, one open pollinated family and one control mass pollinated family) were planted at three densities $\left(618,1235\right.$, and 1853 stems ha $^{-1}$ ) with three or four replications at three sites (Virginia (VA), and North Carolina (NC) in the United States and Paraná State in Brazil (BR)). The VA and BR sites were outside the native range of $P$. taeda. After five years of growth, the BR site had larger trees and stand scale basal area and volume were increasing faster than the other sites. Site did not affect LUE but density and genetic entry did. The sites were at different latitudes but the average photosynthetically active radiation at the top of the canopy was similar for the years when all sites were operational, likely because the BR site receives more rain annually and the cloudiness associated with the rain may have reduced available light. We estimated an hourly heat sum where the daytime temperature was between 5 and $38^{\circ} \mathrm{C}$, hours where vapor pressure deficit exceeded $1.5 \mathrm{kPa}$ and days following nights where nighttime temperatures were less than $0{ }^{\circ} \mathrm{C}$ were excluded. Site was significant for the cumulative volume and heat sum relationship, for a given level of cumulative degree hours the sites ranked BR > VA > NC in cumulative volume. The different growth per unit of degree hours for each site indicated that something other than the heat sum was causing the observed difference in growth. Other factors including respiration and extreme climatic conditions may contribute to growth differences per unit degree hour and including these differences in the analysis would require a more detailed modeling effort to examine. The sites used in this study are ideally suited to continue testing additional hypotheses to explain the different growth between native and exotic $P$. taeda plantations because they have the same genotypes at all sites and consequently eliminate differences in genetics as a potential explanation for observed growth differences.
\end{abstract}

\section{Introduction}

Environmental variables have large effects on tree growth. Trees intercept light and transform light energy into biomass and this transformation is limited by environmental factors affecting photosynthesis (Cannell, 1989b) and light interception is controlled by leaf area (Vose and Allen 1988). Growth per unit intercepted light (light use efficiency (LUE)) has been used to understand how treatments, and

\footnotetext{
* Corresponding author.

E-mail addresses: Tim_Albaugh@vt.edu (T.J. Albaugh), tom.fox@rayonier.com (T.R. Fox), cmaier@fs.fed.us (C.A. Maier), otavio.campoe@ufsc.br (O.C. Campoe), rafaelrubilar@udec.cl (R.A. Rubilar), rlcook@ncsu.edu (R.L. Cook), jayer11@vt.edu (J.E. Raymond)
} 
changes in climate and location influence growth (Albaugh et al., 2016; Monteith 1977; Waring et al., 2016). Heat units have been used since the 1700 s to predict development and growth in crop species (e.g. (McMaster and Wilhelm 1997)) and more recently in tree species (e.g. (Way and Oren 2010)). Heat units can be simply summing of temperatures within a specific threshold or they may include other variables to limit the summing (e.g. vapor pressure deficit (VPD) (Sangines de Carcer et al., 2017) when it is compared to some point of development or cumulative growth. The amount and quality of light and temperature patterns change when moving a species from one location to another. Developing an understanding of how light and temperature affect a given species would help predict how a species will behave in a new environment. For example, the Köppen climate classification system is used to identify similar environmental niches for exotic planting of Eucalyptus species to improve the likelihood a species will be planted successfully in other environments (Goncalves et al., 2013). At the other end of the spectrum, there are species that are already planted in exotic locales and do well (e.g. (Waring et al., 2008)). In this case, improving our understanding of conditions that make a species grow better as an exotic may help improve management in the native range. At the same time, identifying driving factors or relationships similar to LUE and heat sums that influence growth will make this analysis applicable to other species. Pinus taeda L. is one species that may grow extremely well outside its native range (Wallinger, 2002). This species is one of the world's most important commercial species, a native to North America where it is responsible for about $60 \%$ of forestry production in the United States (Prestemon and Abt, 2002). Future climate change may influence the species range in and near its native range (Susaeta et al., 2014). Given that it is already planted extensively in areas where it grows well as an exotic (Argentina and Brazil), P. taeda would be a useful test case to compare native and exotic plantings to develop a better understanding of the factors driving growth. Understanding what drives superior exotic growth may permit improvement in silviculture of native grown $P$. taeda and help relieve pressure on the land base from an increasing population and an increase in demand for forest services predicted in the future (Susaeta et al., 2014).

From the 1940's to the 2000's, improvement in silvicultural practices greatly increased estimated productivity of $P$. taeda plantations grown in the species' native range in the southeastern United States (Fox et al., 2007). There is evidence that maximum growth for the species in its native range is about $16 \mathrm{Mg} \mathrm{ha}^{-1} \mathrm{yr}^{-1}$ (mean annual increment) $\left(40 \mathrm{~m}^{3} \mathrm{ha}^{-1} \mathrm{yr}^{-1}\right.$, assuming $400 \mathrm{~kg} \mathrm{~m}^{-3}$ wood density (Antony et al., 2014)) given that additional silvicultural inputs do not increase productivity beyond this amount (Zhao et al., 2016). Typical mean annual growth rates for $P$. taeda in the southeastern United States range from 16 to $33 \mathrm{~m}^{3} \mathrm{ha}^{-1} \mathrm{yr}^{-1}$ (Zhao et al., 2016). However, the theoretical maximum growth for $P$. taeda was estimated at $30 \mathrm{Mg} \mathrm{ha}^{-1} \mathrm{yr}^{-1}$ mean annual yield $\left(75 \mathrm{~m}^{3} \mathrm{ha}^{-1} \mathrm{yr}^{-1}\right.$ ) (Farnum et al., 1983). When $P$. taeda is grown outside its native range apparent productivity is much higher. For example, $P$. taeda mean annual growth rates of 50,56 and $59 \mathrm{~m}^{3} \mathrm{ha}^{-1} \mathrm{yr}^{-1}$ for stands in Brazil have been reported (Barrichelo et al., 1977; Leite et al., 2006; Wallinger 2002). In Argentina, Pezzutti (2011) reported mean annual volume growth up to $45 \mathrm{~m}^{3} \mathrm{ha}^{-1} \mathrm{yr}^{-1}$. Cubbage et al. (2007) estimated that mean annual increments of 40 and $18 \mathrm{~m}^{3} \mathrm{ha}^{-1} \mathrm{yr}^{-1}$ were possible in Brazil and the United States, respectively, current annual increments would be higher.

A number of hypotheses to explain better exotic plantation growth have been proposed. Rapid growth in Brazil was attributed to a longer growing season, greater sunlight intensity, better soils and lack of pathogens (Wallinger 2002). Harms et al. (1994) suggested that high solar radiation intensities and high sun angles may be responsible for better growth and noted that genetic characteristics may play a role in the differences observed between native and exotic plantations. Physiological assessments (leaf light-saturated net photosynthesis, dark respiration, stomatal conductance and quantum yield) completed on $P$. taeda trees in exotic locations (Hawaii and Brazil) were comparable to those reported in the native range (Samuelson et al., 2010). Samuelson et al. (2010) suggested that better growth in Hawaii may be related to a more favorable climate permitting year-round growth, high nutrient availability, increased flushing and less belowground allocation.

However, few hypotheses have been tested to explain the different growth between native and exotic plantations. Foliage longevity was examined for P. taeda in North Carolina and in Corrientes, Argentina. More foliage was displayed for a shorter time per fascicle in Argentina and while study inference was limited (only one exotic and one native site with different genotypes at each site) most fascicles at both sites survived for two growing seasons, the one in which they were produced and the following one (Albaugh et al., 2010). Waring et al. (2008) used a combination of modeling and direct measurements to determine that summer drought and evaporative demand limitations in native Douglas- fir (Pseudotsuga menziesii (Mirb.) Franco), limit growth to $30 \mathrm{~m}^{3} \mathrm{ha}^{-1} \mathrm{yr}^{-1}$ in managed plantations in its native range in western Oregon in the United States compared to $50 \mathrm{~m}^{3} \mathrm{ha}^{-1} \mathrm{yr}^{-1}$ in exotic plantations in New Zealand from the same seed source that do not experience these moisture limitations. No studies were found in the literature where the same genotypes were planted in the native range and in exotic locations that would permit testing hypotheses to explain the differences in growth and carrying capacity observed between the same species planted in native and exotic locations.

Consequently, we were interested in examining growth, LUE and heat sums in $P$. taeda grown in native and exotic plantations where the genotypes were the same in both locations. Specifically, we examined these hypotheses for P. taeda: (1) Growth is the same for native and exotic plantations; (2) LUE is the same for native and exotic plantations (site does not affect the volume growth and absorbed photosynthetically active radiation relationship); (3) heat sum per unit of volume growth is the same for native and exotic plantations (site does not affect the cumulative volume and degree hour relationship).

\section{Methods}

\subsection{Experimental design}

We installed a split split-plot design with three or four replications at three sites (Vickers et al., 2011). The first site (NC) with three replications was selected in the Atlantic Coastal Plain of North Carolina, United States in Bladen Lakes State Forest at $\left(34.83133^{\circ},-78.5873^{\circ}\right)$ in the native range of $P$. taeda near where the genetic material used in the study was sourced. The second site (VA) had four replications and was in the Piedmont of Virginia, United States at the Reynolds Homestead $\left(36.64232^{\circ},-80.1546138^{\circ}\right)$ in an area where $P$. taeda grows successfully but is outside the native range of the species. The third site (BR) was in Paraná State in Brazil $\left(-26.1904805^{\circ},-49.49631^{\circ}\right)$ with three replications on land owned by Valor Florestal in an area where $P$. taeda is commonly grown as an exotic species. Whole plot treatments were two levels of silviculture, operational to match current operational practices and intensive, which was designed to achieve near maximum growth for the existing soil and climate. For this analysis, we excluded the operational silviculture treatment because competing vegetation interfered with our ability to estimate peak pine leaf area index in this treatment and three of the genetic entries did not have operational silviculture plots at the BR site due to a space limitation at the site and insufficient seedlings at planting. Consequently, we treated the experiment as a split-plot design. Genetic entry was the main-plot treatment and initial density was the split-plot treatment. There were six genetic entries, four clonal varieties (C1, C2, C3, C4), one open pollinated family (OP) and one control mass pollinated family (MP). There were three initial densities, 618, 1235, and 1853 stems ha $^{-1}$. These treatments yielded six main-plots (genetic entry) each with three subplots (initial density) per replicate.

All plots had a treated area with a smaller measurement plot centered in it. The BR site and three replicates at the VA site had 81 trees (9 
rows $\times 9$ planting spots) in each treated plot. The NC site and one replicate at the VA site had 63 trees ( 7 rows $\times 9$ planting spots) in the treated plots. The smaller treated plots were used because of space limitations. Each measurement plot had 25 trees $(5 \times 5)$. Plot size varied with initial density. Distance between rows $(3.66 \mathrm{~m})$ was the same at all sites and treatments. Distance between trees on the row varied with $4.42,2.21$, and $1.47 \mathrm{~m}$ between trees on the row for the 618,1235 , and 1853 stems ha $^{-1}$ initial density treatments, respectively. Plots with different initial density or genotypes were adjacent to each other.

The NC and BR sites were cutover $P$. taeda stands and the VA site was a cutover mixed stand of $P$. taeda, $P$. strobus L. and $P$. virginiana. Soils were well drained Fine, kaolinitic, mesic Typic Kanhapludults at the VA site, somewhat poorly drained Fine-loamy silicieous, semiactive, thermic Typic Paleaqualts at the NC site and well drained Inceptisols and Hapludults at the BR site. The VA and NC sites were planted in 2009 and the BR site was planted in 2011. The genetic entries were the same for all three sites. Containerized seedlings were used for all genetic entries in BR and for the clonal material at VT and NC. The MP and OP genetic entries at VT and NC were bare-root. Mechanical and chemical vegetation control was applied as needed to keep the trees free from competing vegetation at all sites. Fertilizer was applied as needed based on foliar nutrient concentration and leaf area development with the goal to maintain the trees free from nutrient limitations.

Meteorological data (air temperature, relative humidity, precipitation and photosynthetically active radiation (PAR)) were from on-site stations at the VA and NC sites and from an INMET (2017) station (Rio Negrinho Station A862) $10.5 \mathrm{~km}$ away from the BR site. When on-site data were not available, the nearest meteorological station available from CRONOS (2015) was used to fill in data for the VA and NC sites. When the data from the Rio Negrinho site were not available, data from the nearest INMET station with available data was used for the BR site. When above canopy irradiance was not available we used SolarCalc (Spokas and Forcella 2006) to estimate it. Vapor pressure deficit was calculated as:

$\mathrm{VPD}=(1-(\mathrm{RH} / 100)) *\left(\left(610.7 * 10^{(7.5 * \mathrm{~T} / 237.3+\mathrm{T})}\right) / 1000\right)$

where VPD was vapor pressure deficit in $\mathrm{kPa}$, $\mathrm{RH}$ was relative humidity in percent, and $\mathrm{T}$ was air temperature in ${ }^{\circ} \mathrm{C}$.

Diameter at breast height $(1.3 \mathrm{~m})$ and height were measured on all live trees annually. Individual tree volume was calculated from diameter at breast height and height using an equation from Tasissa et al. (1997). Individual tree volume and basal area were summed by plot and scaled to a hectare basis. Incremental data was estimated as the most recent measurement minus the measurement from the previous year. The last measurement at the BR site was taken at 5.4 years; we scaled the diameter and height measurements for each tree from 4 years to 5.4 years by 0.714 ( 1 year divided by 1.4 years) to estimate 5 year data and used these data to estimate basal area and volume. Leaf area index was measured using a LICOR LAI 2200 Plant Canopy Analyzer with a $10^{\circ}$ view cap. Peak leaf area index measurements were collected in August for the VA and NC sites and in January for the BR site. Off peak measurements were collected in January for the VA and NC sites and in July for the BR site. Post processing of the LICOR data included dropping the fifth ring for measurements in the 1236 and 1854 trees $\mathrm{ha}^{-1}$ plots because this ring sampled outside the plot area for these treatments.

\subsection{Statistical analyses}

To examine our first hypothesis, we used a mixed model approach (PROC MIXED (SAS-Institute 2002)) to test for treatment effects for all sites after five years for diameter, diameter increment, height, height increment, basal area, basal area increment, volume, volume increment, and stand density. This approach was used to examine treatment effects on peak leaf area index and off peak leaf area index for the fifth year at the BR site and for the eighth year at the VA and NC sites. Leaf area index was not measured in the fifth year at the VA and NC sites. Site, density, genetic entry and their interactions were fixed effects. Random effects were block and genetic entry by block (Schabenberger, 2013). Site was considered a fixed effect because we selected sites in specific areas (inside and outside the native range of $P$. taeda) (Littell et al., 2006; Piepho et al., 2003). We considered blocks as replicates, there were a total of 10 blocks (4, 3 and 3 from the VA, NC and BR sites, respectively). We sliced by site with the other fixed effects to determine significant interactions with site. We used the Tukey-Kramer adjustment to determine means separation.

To examine our second hypothesis, we developed a regression equation for the volume growth and intercepted light (LUE) relationship using a mixed effects model. The full model was:

\section{VI $=$ I S D G I*S I*D I*G S*D S*G D*G I*S*D I*S*G I*D*G S*D*G $I^{*} \mathrm{~S}^{*} \mathrm{D} * \mathrm{G}$}

where VI was volume growth $\left(\mathrm{m}^{3} \mathrm{ha}^{-1} \mathrm{yr}^{-1}\right)$ for the eighth growing season at the VA and NC sites and the fifth growing season at the BR site, I was intercepted light (absorbed PAR ( $\mathrm{MJ} \mathrm{m}^{-2} \mathrm{yr}^{-1}$ )) corresponding to the volume increment data, S, D and G were class variables for site, density and genetic entry, respectively. We estimated absorbed PAR as

$\mathrm{I}_{\mathrm{ABS}}=\mathrm{I}_{\mathrm{O}}\left[1-\exp ^{(-\mathrm{kL})}\right]$

where $\mathrm{I}_{\mathrm{O}}$ was above-canopy irradiance, $\mathrm{k}$ was the extinction coefficient (0.5, (Sampson and Allen, 1995)), and L was peak leaf area index (Landsberg, 1986). Above canopy irradiance was the annual sum of all the hourly PAR data from the meteorological stations mentioned above. The year corresponding to volume growth for the VA and NC sites was the calendar year (January 1 to December 31), for the BR site it was July 1 to June 30 . Block and block by genetic entry were random effects. Non-significant terms were dropped from the model until all terms in the model were significant.

To examine our third hypothesis, we calculated cumulative volume for each plot for each year at the three sites. Plot volume for each year was averaged across site because our meteorological data were at the site scale. Our meteorological data were on an hourly basis, consequently we estimated a degree hour metric for our heat sum. We estimated the hourly heat sum two ways. First, the heat sum was the cumulative degree hours greater than $5{ }^{\circ} \mathrm{C}$ where ambient temperature was between 5 and $38^{\circ} \mathrm{C}$ (Ellsworth, 2000; Tang et al., 1999) and photosynthetically active radiation was greater than 0 (daytime). If the preceding nighttime temperature was less than $0{ }^{\circ} \mathrm{C}$, all hours the next day were assigned a 0 value for the heat sum (Teskey et al., 1987). For a given hour, if the ambient temperature was $5{ }^{\circ} \mathrm{C}$, it was during the day and the previous nighttime temperatures were above zero then the heat sum for that hour was 5-5 or 0 . If under the same conditions, the ambient temperature was $30^{\circ} \mathrm{C}$ then the heat sum for that hour was 30 5 or 25 . The second method to estimate the heat sum was the same as the first with an additional criteria where hours where the VPD exceeded $1.5 \mathrm{kPa}$ were assigned a 0 value for the heat sum (Tang et al., 1999). For each site, all the hourly heat sums for the year were summed for the cumulative degree hour statistic. We developed a regression equation for the cumulative volume growth and cumulative degree hour relationship to test for site effects. The full model was:

$\mathrm{CV}=\mathrm{DH} \mathrm{S} \mathrm{DH} * \mathrm{~S}$

where $\mathrm{CV}$ was cumulative volume in $\mathrm{m}^{3} \mathrm{ha}^{-1}$ for each site at year end as an average of all individual plot estimates of volume, $\mathrm{DH}$ was the cumulative degree hour statistic and $\mathrm{S}$ was a class variable indicating each site. Non-significant terms were dropped from the model until all terms in the model were significant. Residuals indicated a $\log \log$ transformation was appropriate to eliminate bias and heteroscedasticity. The Baskerville (1972), correction was applied when converting back to real scale. 
Table 1

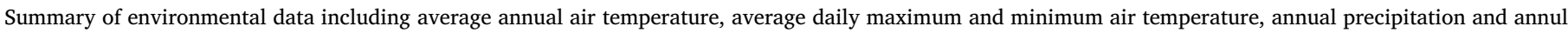

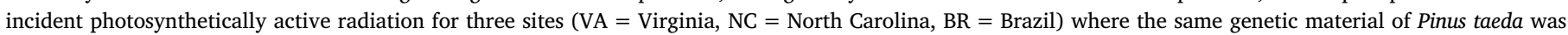
planted at all sites.

\begin{tabular}{|c|c|c|c|c|c|c|}
\hline \multirow[b]{3}{*}{ Site } & \multirow[b]{3}{*}{ Year } & \multicolumn{3}{|l|}{ Air temperature } & \multirow[t]{2}{*}{ Precipitation } & \multirow[t]{3}{*}{ Photosynthetically active radiation } \\
\hline & & Average annual & Average daily maximum & minimum & & \\
\hline & & ${ }^{\circ} \mathrm{C}$ & ${ }^{\circ} \mathrm{C}$ & ${ }^{\circ} \mathrm{C}$ & $\mathrm{mm} \mathrm{yr}^{-1}$ & \\
\hline VA & 2009 & 13.1 & 19.0 & 7.6 & 1280 & 2236 \\
\hline VA & 2010 & 13.4 & 19.9 & 7.6 & 1107 & 2324 \\
\hline VA & 2011 & 14.0 & 20.2 & 8.4 & 1340 & 2251 \\
\hline VA & 2012 & 14.2 & 20.3 & 8.6 & 1266 & 2217 \\
\hline VA & 2013 & 13.1 & 18.8 & 8.0 & 1305 & 2243 \\
\hline VA & 2014 & 12.8 & 18.9 & 7.1 & 1104 & 2315 \\
\hline VA & 2015 & 13.9 & 19.9 & 8.4 & 1421 & 2179 \\
\hline VA & 2016 & 13.7 & 19.9 & 8.1 & 919 & 2181 \\
\hline NC & 2009 & 16.8 & 24.3 & 10.4 & 1218 & 2442 \\
\hline NC & 2010 & 16.5 & 24.8 & 9.7 & 1169 & 2702 \\
\hline NC & 2011 & 17.0 & 25.1 & 10.3 & 945 & 2701 \\
\hline NC & 2012 & 17.2 & 25.4 & 10.6 & 1051 & 2808 \\
\hline NC & 2013 & 15.9 & 24.5 & 8.7 & 1175 & 2422 \\
\hline NC & 2014 & 15.3 & 24.8 & 7.4 & 996 & 2120 \\
\hline NC & 2015 & 16.7 & 25.7 & 9.4 & 1204 & 2063 \\
\hline NC & 2016 & 16.5 & 25.9 & 9.3 & 1397 & 2034 \\
\hline $\mathrm{BR}$ & 2011 & 16.0 & 21.8 & 12.3 & 1692 & 2431 \\
\hline BR & 2012 & 17.0 & 23.4 & 13.0 & 1600 & 2482 \\
\hline $\mathrm{BR}$ & 2013 & 16.3 & 22.4 & 12.2 & 1706 & 2398 \\
\hline BR & 2014 & 17.3 & 23.3 & 13.4 & 1615 & 2445 \\
\hline BR & 2015 & 17.5 & 23.3 & 13.8 & 1488 & 2244 \\
\hline BR & 2016 & 16.6 & 22.8 & 12.5 & 1376 & 2401 \\
\hline
\end{tabular}

All statistical tests were evaluated with alpha equal to 0.05 . Residuals were examined for bias for all statistical tests; none was found except as previously noted.

\section{Results}

Average annual air temperature was $13.5,16.5$, and $16.8^{\circ} \mathrm{C}$ for the $\mathrm{VA}, \mathrm{NC}$ and $\mathrm{BR}$ sites, respectively (Table 1 ). Average annual precipitation was 1218,1144 , and $1580 \mathrm{~mm} \mathrm{yr}^{-1}$ for the VA, NC and BR sites, respectively. Average annual photosynthetically active radiation for 2011-2016 (the years when all three sites were operational) was 2231,2358 , and $2400 \mathrm{MJ} \mathrm{m}^{-2} \mathrm{yr}^{-1}$ for the VA, NC and BR sites, respectively. During the year, temperatures were out of phase with high temperatures at the VA and NC sites in July corresponding to low temperatures in the same month at the BR site (Fig. 2a-c). Annual temperature fluctuations from minimum mean monthly temperature to maximum mean monthly temperature were -3 to $29^{\circ} \mathrm{C},-1$ to $35^{\circ} \mathrm{C}$, and 8 to $27^{\circ} \mathrm{C}$ for the VA, NC and BR sites, respectively. Average daily VPD ranged from 0.25 to $0.75,0.22$ to 1.0 , and 0.18 to $0.46 \mathrm{kPa}$ at the VA, NC and BR sites, respectively (Fig. 2d). Average monthly photosynthetically active radiation ranged from 83 to 277,85 to 302 , and 116 to $278 \mathrm{MJ} \mathrm{m}^{-2} \mathrm{mo}^{-1}$ at the VA, NC and BR sites, respectively (Fig. 2e). Similar to temperature, VPD and photosynthetically active radiation were out of phase with the sites in North America having high values when the site in South America had low values and vice versa. During the year, precipitation ranged from 60 to $180 \mathrm{~mm} \mathrm{month}^{-1}$ across all three sites (Fig. 2f).

Site effects were significant for all growth metrics (diameter, diameter increment, height, height increment, basal area, basal area increment, volume, volume increment, stand density, peak and off-peak leaf area index) (Table 2). The BR site had greater diameter, height, basal area, basal area increment, volume, volume increment, stand density, peak and off-peak leaf area than the VA and NC sites (Table 3a). Diameter increment at the BR site was smaller than at the NC site and height increment at the BR site was less than that at the VA and NC sites. Site average density (an indicator of survival) was 91, 87, $99 \%$ at the VA, NC and BR sites, respectively. Most mortality at all sites appeared in the first year. No mortality had occurred at the BR site after the first year however, additional mortality was evident at the NC site in the 1235 and 1854 trees ha $^{-1}$ treatments. Peak and off-peak leaf area indices were similar at the VA and NC sites. At the BR site, peak and offpeak leaf area indices were 72 and $119 \%$ greater than the average of the corresponding values at the VA and NC sites, respectively.

Density significantly influenced all growth metrics (Table 2). Density main effects generally followed similar patterns at all sites where tree scale metrics (diameter, diameter increment, height and height increment) either decreased with increasing density or stayed the same (Table 3a). At the same time, stand scale metrics (basal area, basal area increment, volume, and volume increment) increased with increasing density. The general patterns of response were similar across sites however, the magnitude of the differences between density treatments at the different sites was different and resulted in a significant site by density interaction for all growth metrics except height. For example, basal area increment more than doubled (more than 100\% increase) going from the low to high density treatment at the VA and NC site whereas at the BR site the corresponding increase was about $56 \%$. Density was generally less for the mass-control pollinated and open pollinated genetic entries than the other genetic entries at the VA and NC sites, respectively. Early survival was less for these genetic entries likely because they were planted as bare root seedlings whereas the other genetic entries at the VT and NC sites were containerized seedlings. All genetic entries at the BR sites were planted as containerized seedlings.

Genetic entry significantly influenced all growth metrics except for height and off-peak leaf area index (Table 2). For a given site, detectable differences were observed among genetic entries for most growth metrics (Table 3b). For example, at the VA site, a difference among the genetic entries was observed for all growth metrics except diameter increment, peak and off-peak leaf area index. A genetic entry by site interaction was found for all growth metrics except peak leaf area index such that a different genetic entry typically grew the best at each site. Clone 2 performed the best at the NC site having the greatest growth or tied for greatest growth for diameter, height, height increment, basal area, basal area increment, volume, volume increment and density. At 

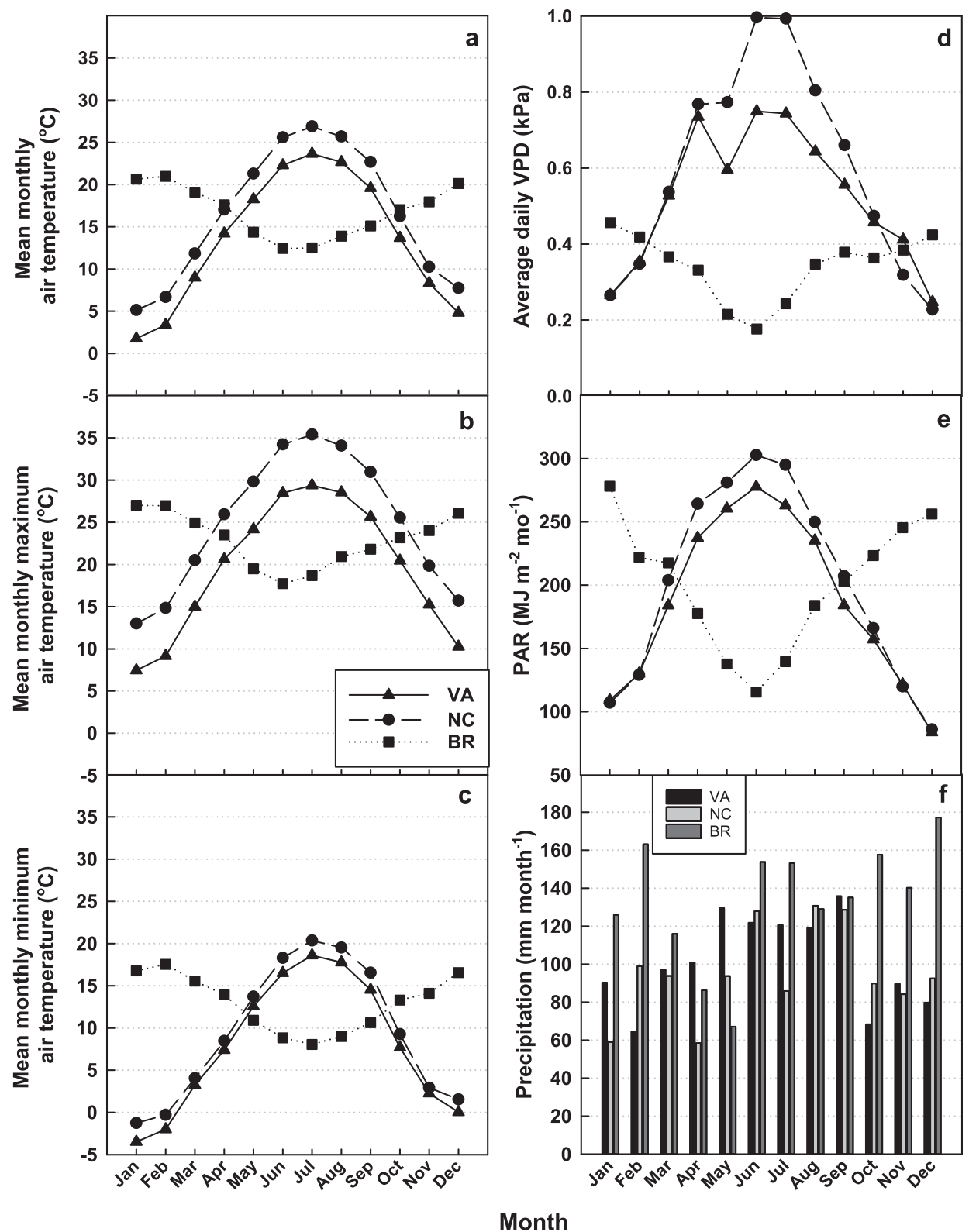

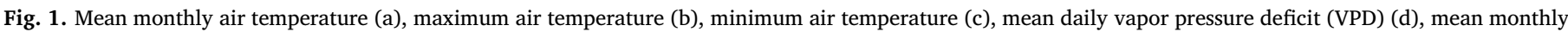

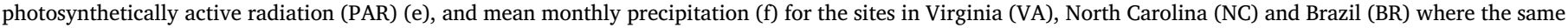
Pinus taeda genetic entries were planted at three initial densities.

the BR site, the open pollinated family performed the best and at the VA site, clones 2 and 4 typically performed the best.

Absorbed photosynthetically active radiation, genetic entry, density and absorbed photosynthetically active radiation by genetic entry were significant terms in the LUE analysis (Table 4). Site was not a significant term in this analysis. For the open pollinated genetic entry and an absorbed photosynthetically active radiation of $1600 \mathrm{MJ} \mathrm{m}^{-2} \mathrm{yr}^{-1}$, predicted volume growth was $22.9,32.9,42.2 \mathrm{~m}^{3} \mathrm{ha}^{-1} \mathrm{yr}^{-1}$ for the densities of 618, 1236, 1854 trees $^{-}{ }^{-}$, respectively (Fig. 2a). For a density of 1854 trees ha ${ }^{-1}$ and an absorbed photosynthetically active radiation of $1600 \mathrm{MJ} \mathrm{m}^{-2} \mathrm{yr}^{-1}$, predicted volume growth was 47.6, 43.9, 45.5, 48.1, 45.2, and $42.2 \mathrm{~m}^{3} \mathrm{ha}^{-1} \mathrm{yr}^{-1}$ for C1, C2, C3, C4, MP and OP genetic entries, respectively (Fig. 2b). The overall slope of the equation was positive (0.0222 Table 4). However, the interaction term of absorbed photosynthetically active radiation by genetic entry had negative parameter estimates which resulted in a near zero slope (no/little change in volume growth with increasing absorbed photosynthetically active radiation) for C3 and a negative slope (decreasing volume growth with increasing absorbed photosynthetically active radiation) for C4.

With no adjustment for VPD, the NC site accumulates about twice as many degree hours in the last year measured than the BR site with the VA site intermediate between the NC and BR sites (Fig. 3a). Setting hours where VPD was greater than $1.5 \mathrm{kPa}$ to 0 for the cumulative degree hour calculation reduces the cumulative degree hours for the NC and VA sites much closer to the BR site values (Fig. 3b). Cumulative degree hours and site were significant independent variables explaining cumulative volume. For a given level of cumulative degree hours the sites rank BR > VA > NC for cumulative volume. For example, the last measurement at the BR site was from the fifth year of growth when cumulative volume was $102 \mathrm{~m}^{3} \mathrm{ha}^{-1}$ and cumulative degree hours totaled 270,000. After the seventh year of growth at the VA and NC sites, cumulative degree hours were 266,000 and 272,000, respectively, however, cumulative volume was 91 and $73 \mathrm{~m}^{3} \mathrm{ha}^{-1}$, respectively. 


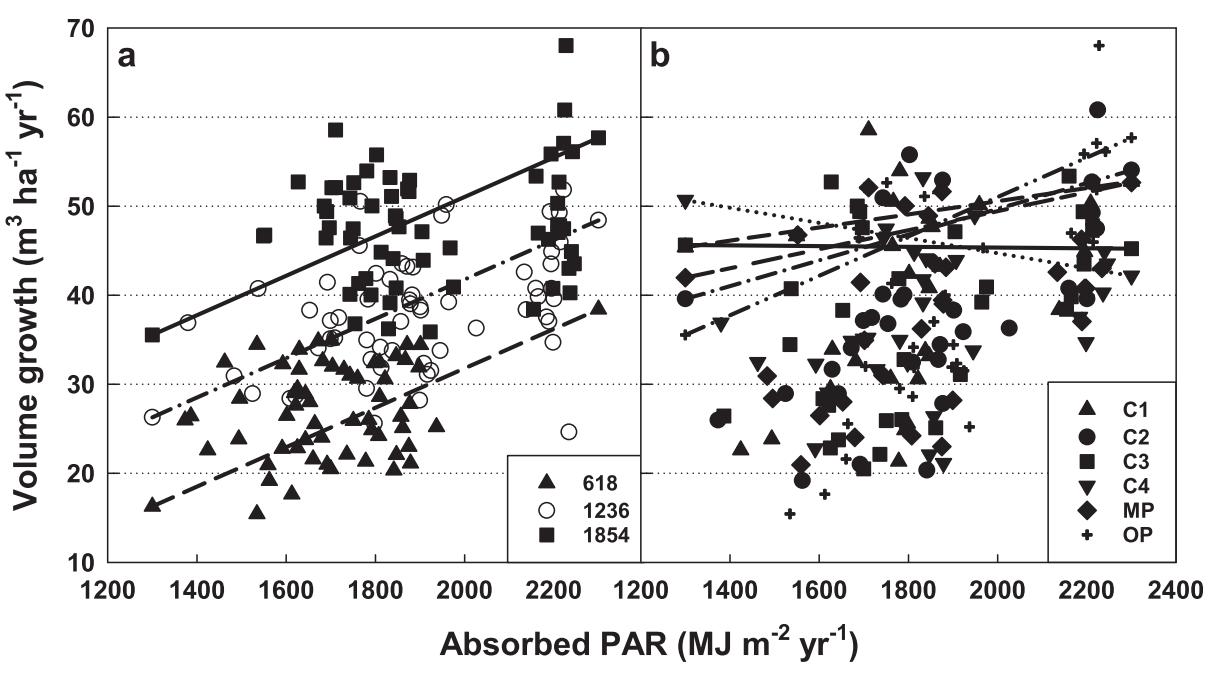

Fig. 2. Light use efficiency (volume growth per unit absorbed photosynthetically active radiation (PAR)) for the eighth growth season at the Virginia (VA) and North Carolina (NC) sites and the fifth growing season at the Brazil (BR) site where the same Pinus taeda genetic entries were planted at three initial densities. Regression lines are for density main effects (a) where 618,1236 and 1854 represent the corresponding density treatments (in trees $\mathrm{ha}^{-1}$ ) with the open pollinated genetic entry, and genetic entry main effects (b) (Clones 1-4 (C1-C4), MP (mass control pollinated), and OP (open pollinated)) with 1854 tree ha $^{-1}$. Site was not a significant factor in the relationship. Each point represents one plot.

\section{Discussion}

Site did affect growth and, consequently, we rejected our first hypothesis. Individual trees at the BR site were larger in both height and diameter then those at the VA and NC sites (Table 3a). Height increments at the BR site were less than those at the VA and NC sites and the $\mathrm{BR}$ site diameter increment was less than the NC site diameter increment. It is likely that the BR site height increments had culminated similar to that observed in other studies where $P$. taeda was planted as an exotic and the maximum height increment was observed at or before age six or seven years (Harms et al., 2000; Pezzutti, 2011). In the native range, height increment culminates at a later age, about ten to twelve years (e.g. (Martin and Jokela, 2004)). At the same time, the diameter increment at the BR site was growing on a larger tree indicating that the total amount of stem wood required to produce this amount of diameter increment was much greater than that at the VA and NC sites and this was reflected in the stand scale measurements. Brazil site basal area and volume increments were 67 and $129 \%$, respectively, greater than corresponding growth at the VA and NC site at least in part due to better survival across all densities at the BR site. Current volume increment for the BR site $\left(40 \mathrm{~m}^{3} \mathrm{ha}^{-1} \mathrm{yr}^{-}\right)$was more than twice that found at the VA $\left(19 \mathrm{~m}^{3} \mathrm{ha}^{-1} \mathrm{yr}^{-1}\right)$ and NC $\left(15 \mathrm{~m}^{3} \mathrm{ha}^{-1} \mathrm{yr}^{-1}\right)$ sites. On average, by age five, the BR site had achieved growth rates near the expected maximum for native range plantations ( $\left.\sim 40 \mathrm{~m}^{3} \mathrm{ha}^{-1} \mathrm{yr}^{-1}\right)$ (Zhao et al., 2016). The BR site high density treatment was growing at $50 \mathrm{~m}^{3} \mathrm{ha}^{-1} \mathrm{yr}^{-1}$, which was in the range of growth rates observed in previous work in Brazil (50-59 $\mathrm{m}^{3} \mathrm{ha}^{-1} \mathrm{yr}^{-1}$ (Barrichelo et al., 1977; Leite et al., 2006; Wallinger, 2002). The stand was only five years old at this assessment and has the potential to exceed the current growth rate in the coming years. It will be interesting to see how close to the theoretical maximum of $30 \mathrm{Mg} \mathrm{ha}^{-1} \mathrm{yr}^{-1}\left(75 \mathrm{~m}^{3} \mathrm{ha}^{-1} \mathrm{yr}^{-1}\right)$ (Farnum et al., 1983) that this stand can come.

Site did not affect the LUE relationship for stem volume growth. Consequently, we accepted our second hypothesis. This is in agreement with other work where site and species did not affect stem growth LUE for a range of species and sites (Albaugh et al., 2016; Cannell 1989a; Linder, 1985). Although previous investigators (Harms et al., 1994; Wallinger 2002) suggested that differences in light intensity may be influencing the different growth in native and exotic plantations our findings indicate that this may not be important in explaining the observed growth differences. We did not adjust for clumping in our leaf area measurements assuming that the effects would be the same at all sites given the same genetic entries were planted at each site. However, Kim et al. (2011) found that overestimation of absorbed light was possible if not adjusting for clumping even in highly clumped coniferous species. The sites are at different latitudes (VA at $36.6^{\circ}, \mathrm{NC}$ at $34.8^{\circ}$, and $\mathrm{BR}$ at $-26.2^{\circ}$ ) but the average photosynthetically active radiation at the top of the canopy was not all that different for the years 2011-2016 (2231, 2358, $2400 \mathrm{MJ} \mathrm{m}^{-2} \mathrm{yr}^{-1}$ for VA, NC and BR sites, respectively (Table 1$)$ ) when all sites were operational. There was less precipitation at the VA $\left(354 \mathrm{~mm} \mathrm{yr}^{-1}(29 \%)\right)$ and NC $\left(452 \mathrm{~mm} \mathrm{yr}^{-1}\right.$ (40\%)) sites compared to the BR site (Table 1). Additional precipitation implies greater cloud cover that would reduce light levels and this may explain the similar incoming light levels at the three sites. There is evidence to suggest that greater cloud cover increases diffuse radiation and the diffuse radiation allows for greater penetration of light into the canopy and enhances overall photosynthesis by transferring the radiation load from light saturated sunlit leaves to non-saturated shade leaves (Knohl and Baldocchi, 2008). This may help explain the relatively high peak leaf area indices observed at the BR site where foliage deeper in the canopy received enough light to survive. If this occurred in our systems, it may not have made enough of a difference for us to

Table 2

Statistical summary (p values) for stand and growth increment metrics for three sites (Virginia (VA), North Carolina (NC) and Brazil (BR)) where Pinus taeda was planted using the same six genetic entries and three initial density levels. Growth data for all sites are after 5 years and the fifth growing season increment. Leaf area data for the BR site are from the fifth year, leaf area data for the VA and NC sites are for the eighth year.

\begin{tabular}{|c|c|c|c|c|c|c|c|c|c|c|c|}
\hline & Diameter & $\begin{array}{l}\text { Diameter } \\
\text { increment }\end{array}$ & Height & Height increment & Basal area & $\begin{array}{l}\text { Basal area } \\
\text { increment }\end{array}$ & Volume & Volume increment & Density & $\begin{array}{l}\text { Peak leaf } \\
\text { area index }\end{array}$ & $\begin{array}{l}\text { Off-Peak leaf } \\
\text { area index }\end{array}$ \\
\hline Site $(S)$ & 0.000 & 0.016 & 0.000 & 0.001 & 0.000 & 0.000 & 0.000 & 0.000 & 0.003 & 0.000 & 0.000 \\
\hline Genetic Entry (G) & 0.000 & 0.000 & 0.074 & 0.000 & 0.000 & 0.000 & 0.000 & 0.000 & 0.000 & 0.026 & 0.059 \\
\hline $\mathrm{S}^{*} \mathrm{G}$ & 0.000 & 0.038 & 0.000 & 0.000 & 0.000 & 0.001 & 0.000 & 0.000 & 0.000 & 0.068 & 0.018 \\
\hline$S^{*} \mathrm{D}$ & 0.000 & 0.000 & 0.899 & 0.000 & 0.000 & 0.002 & 0.000 & 0.000 & 0.000 & 0.000 & 0.000 \\
\hline$G^{*} \mathrm{D}$ & 0.401 & 0.170 & 0.816 & 0.035 & 0.086 & 0.972 & 0.061 & 0.931 & 0.000 & 0.646 & 0.313 \\
\hline$S^{*} G^{*} D$ & 0.051 & 0.447 & 0.063 & 0.001 & 0.006 & 0.834 & 0.000 & 0.210 & 0.340 & 0.667 & 0.202 \\
\hline
\end{tabular}


Table 3a

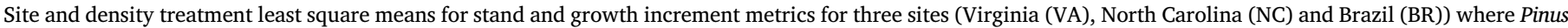

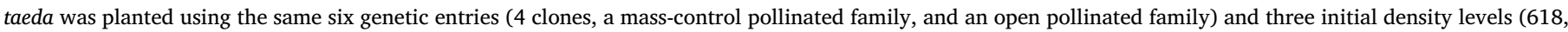

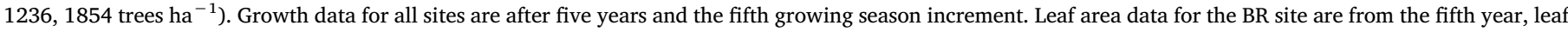

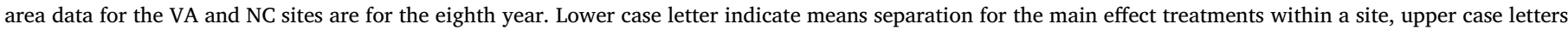
indicate means separation among sites.

\begin{tabular}{|c|c|c|c|c|c|c|c|c|c|c|c|c|c|}
\hline Site & Effect & Level & $\begin{array}{l}\text { Diameter } \\
(\mathrm{cm})\end{array}$ & $\begin{array}{l}\text { Diameter } \\
\text { increment } \\
\left(\mathrm{cm} \mathrm{yr}^{-1}\right)\end{array}$ & $\begin{array}{l}\text { Height } \\
\text { (m) }\end{array}$ & $\begin{array}{l}\text { Height } \\
\text { increment } \\
\left(\mathrm{m} \mathrm{yr}^{-1}\right)\end{array}$ & $\begin{array}{l}\text { Basal area } \\
\left(\mathrm{m}^{2} \mathrm{ha}^{-1}\right)\end{array}$ & $\begin{array}{l}\text { Basal area } \\
\text { increment } \\
\left(\mathrm{m}^{2} \mathrm{ha}^{-1} \mathrm{yr}^{-1}\right)\end{array}$ & $\begin{array}{l}\text { Volume } \\
\left(\mathrm{m}^{3} \mathrm{ha}^{-1}\right)\end{array}$ & $\begin{array}{l}\text { Volume } \\
\text { increment } \\
\left(\mathrm{m}^{3} \mathrm{ha}^{-1} \mathrm{yr}^{-1}\right)\end{array}$ & $\begin{array}{l}\text { Density } \\
\text { (trees ha }{ }^{-1} \text { ) }\end{array}$ & $\begin{array}{l}\text { Peak leaf } \\
\text { area index } \\
\left(\mathrm{m} \mathrm{m}^{-2}\right)\end{array}$ & $\begin{array}{l}\text { Off-Peak leaf } \\
\text { area index } \\
\left(\mathrm{m} \mathrm{m}^{-2}\right)\end{array}$ \\
\hline VA & Site & VA & $10.4 \mathrm{~A}$ & $3.3 \mathrm{AB}$ & $6.4 \mathrm{~A}$ & $1.6 \mathrm{~A}$ & $10.3 \mathrm{~A}$ & $5.3 \mathrm{~A}$ & $38 \mathrm{~A}$ & $19 \mathrm{~A}$ & $1121 \mathrm{~A}$ & $3.5 \mathrm{~A}$ & $2.6 \mathrm{~A}$ \\
\hline NC & & NC & $9.7 \mathrm{~A}$ & $3.5 \mathrm{~B}$ & $6.0 \mathrm{~A}$ & $1.7 \mathrm{~A}$ & $8.1 \mathrm{~B}$ & $4.6 \mathrm{~B}$ & $29 \mathrm{~B}$ & $15 \mathrm{~B}$ & $1078 \mathrm{~A}$ & $3.6 \mathrm{~A}$ & $2.7 \mathrm{~A}$ \\
\hline $\mathrm{BR}$ & & $\mathrm{BR}$ & $16.5 \mathrm{~B}$ & $3.2 \mathrm{~A}$ & $8.4 \mathrm{~B}$ & $1.2 \mathrm{~B}$ & $24.7 \mathrm{C}$ & $8.3 \mathrm{C}$ & $100 \mathrm{C}$ & $40 \mathrm{C}$ & $1219 \mathrm{~B}$ & $6.1 \mathrm{~B}$ & $5.8 \mathrm{~B}$ \\
\hline VA & Density & 618 & $11.1 \mathrm{a}$ & $3.6 \mathrm{a}$ & $6.3 \mathrm{a}$ & $1.5 \mathrm{a}$ & $6.1 \mathrm{a}$ & $3.2 \mathrm{a}$ & $21 \mathrm{a}$ & $11 \mathrm{a}$ & $556 \mathrm{a}$ & $3.1 \mathrm{a}$ & $2.3 \mathrm{a}$ \\
\hline VA & & 1236 & $10.3 \mathrm{~b}$ & $3.3 \mathrm{~b}$ & $6.4 \mathrm{a}$ & $1.7 \mathrm{~b}$ & $10.6 \mathrm{~b}$ & $5.4 \mathrm{~b}$ & $39 \mathrm{~b}$ & $20 \mathrm{~b}$ & $1124 \mathrm{~b}$ & $3.8 \mathrm{~b}$ & $2.8 \mathrm{a}$ \\
\hline VA & & 1854 & $9.8 \mathrm{~b}$ & $3.0 \mathrm{c}$ & $6.5 \mathrm{a}$ & $1.8 \mathrm{~b}$ & $14.2 \mathrm{c}$ & $7.2 \mathrm{c}$ & $54 \mathrm{c}$ & $27 \mathrm{c}$ & $1682 \mathrm{c}$ & $3.7 \mathrm{~b}$ & $2.8 \mathrm{a}$ \\
\hline NC & Density & 618 & $10.4 \mathrm{a}$ & $3.9 \mathrm{a}$ & $5.9 \mathrm{a}$ & $1.6 \mathrm{a}$ & $4.8 \mathrm{a}$ & $2.8 \mathrm{a}$ & $16 \mathrm{a}$ & $9 \mathrm{a}$ & $528 \mathrm{a}$ & $3.2 \mathrm{a}$ & $2.3 \mathrm{a}$ \\
\hline NC & & 1236 & $9.7 \mathrm{~b}$ & $3.5 \mathrm{~b}$ & $6.0 \mathrm{a}$ & $1.7 \mathrm{ab}$ & $8.3 \mathrm{~b}$ & $4.8 \mathrm{~b}$ & $30 \mathrm{~b}$ & $16 \mathrm{~b}$ & $1065 \mathrm{~b}$ & $3.9 \mathrm{~b}$ & $3.0 \mathrm{~b}$ \\
\hline NC & & 1854 & $9.1 \mathrm{~b}$ & $3.1 \mathrm{c}$ & $6.0 \mathrm{a}$ & $1.8 \mathrm{~b}$ & $11.0 \mathrm{c}$ & $6.2 \mathrm{c}$ & $41 \mathrm{c}$ & $21 \mathrm{c}$ & $1641 \mathrm{c}$ & $3.8 \mathrm{ab}$ & $2.9 \mathrm{~b}$ \\
\hline $\mathrm{BR}$ & Density & 618 & $18.3 \mathrm{a}$ & $4.1 \mathrm{a}$ & $8.2 \mathrm{a}$ & $1.2 \mathrm{a}$ & $15.6 \mathrm{a}$ & $6.2 \mathrm{a}$ & $61 \mathrm{a}$ & $27 \mathrm{a}$ & $584 \mathrm{a}$ & $3.3 \mathrm{a}$ & $4.0 \mathrm{a}$ \\
\hline BR & & 1236 & $16.4 \mathrm{~b}$ & $3.1 \mathrm{~b}$ & $8.4 \mathrm{a}$ & $1.1 \mathrm{a}$ & $26.2 \mathrm{~b}$ & $8.9 \mathrm{~b}$ & $105 \mathrm{~b}$ & $42 \mathrm{~b}$ & $1209 \mathrm{~b}$ & $7.1 \mathrm{~b}$ & $6.3 \mathrm{~b}$ \\
\hline BR & & 1854 & $14.8 \mathrm{c}$ & $2.4 \mathrm{c}$ & $8.6 \mathrm{a}$ & $1.2 \mathrm{a}$ & $32.4 \mathrm{c}$ & $9.7 \mathrm{c}$ & $133 \mathrm{c}$ & $50 \mathrm{c}$ & $1865 \mathrm{c}$ & $8.0 \mathrm{c}$ & $7.2 \mathrm{c}$ \\
\hline
\end{tabular}

detect a site effect in LUE. If this is the case, it may be that the foliage lower in the canopy may not be adding that much total additional carbon to the tree and may simply be maintaining itself (Cregg et al., 1993; Sprugel et al., 1991). We examined volume growth per unit leaf area index (growth efficiency (GE)) but did not present this information here because the results were similar to the LUE relationship where site did not influence the relationship. The similar response for LUE and GE lends some support to the hypothesis that foliage in the lower canopy may be maintaining itself rather than making a large contribution to overall growth. However, this analysis focused on stem growth only, if trees in BR are fixing more carbon but allocating it to other plant components like roots, foliage and branches, our analysis would not have detected it. Based on the amount of leaf area produced in BR compared to the VA and NC sites it is likely that the trees in BR are allocating more carbon to foliage if foliage longevity is not different among sites (Albaugh et al., 2010). This would imply that LUE may be affected by site when examining total biomass production at the three sites. However, in a study examining a wide range of species covering three genera with large differences in leaf area development and sites around the world, site did not significantly affect the stem only or total biomass production and intercepted light relationships (Albaugh et al., 2016).

Density and genotype did affect LUE. Density significantly influenced the intercept of the LUE relationship where increasing the

Table 3b

Genetic entry treatment least square means for stand and growth increment metrics for three sites (Virginia (VA), North Carolina (NC) and Brazil (BR)) where Pinus taeda was planted using the same six genetic entries (4 clones (C1, C2, C3, C4), a mass-control pollinated family (MP), and an open pollinated family (OP)) and three initial density levels $\left(618,1236,1854\right.$ trees $\left.\mathrm{ha}^{-1}\right)$. Growth data for all sites are after five years and the fifth growing season increment. Leaf area data for the BR site are from the fifth year, leaf area data for the VA and NC sites are for the eighth year. Lower case letters indicate means separation for the main effect treatment within a site.

\begin{tabular}{|c|c|c|c|c|c|c|c|c|c|c|c|c|c|}
\hline Site & Effect & Level & Diameter & $\begin{array}{l}\begin{array}{l}\text { Diameter } \\
\text { increment }\end{array} \\
\left(\mathrm{cm} \mathrm{yr}^{-1}\right)\end{array}$ & $\begin{array}{l}\text { Height } \\
\text { (m) }\end{array}$ & $\begin{array}{l}\text { Height } \\
\text { increment } \\
\left(\mathrm{m} \mathrm{yr}^{-1}\right)\end{array}$ & $\begin{array}{l}\text { Basal area } \\
\left(\mathrm{m}^{2} \mathrm{ha}^{-1}\right)\end{array}$ & $\begin{array}{l}\text { Basal area } \\
\text { increment } \\
\left(\mathrm{m}^{2} \mathrm{ha}^{-1} \mathrm{yr}^{-1}\right)\end{array}$ & $\begin{array}{l}\text { Volume } \\
\left(\mathrm{m}^{3} \mathrm{ha}^{-1}\right)\end{array}$ & $\begin{array}{l}\text { Volume } \\
\text { increment } \\
\left(\mathrm{m}^{3} \mathrm{ha}^{-1} \mathrm{yr}^{-1}\right)\end{array}$ & $\begin{array}{l}\text { Density } \\
\text { (trees ha }{ }^{-1} \text { ) }\end{array}$ & $\begin{array}{l}\text { Peak leaf } \\
\text { area index } \\
\left(\mathrm{m} \mathrm{m}^{-2}\right)\end{array}$ & $\begin{array}{l}\text { Off-Peak } \\
\text { Leaf area } \\
\text { index } \\
\left(\mathrm{m} \mathrm{m}^{-2}\right)\end{array}$ \\
\hline VA & $\begin{array}{l}\text { Genetic } \\
\text { entry }\end{array}$ & $\mathrm{C} 1$ & $10.4 \mathrm{ab}$ & $3.2 \mathrm{a}$ & $6.5 \mathrm{ab}$ & $1.6 \mathrm{ab}$ & $10.4 \mathrm{ab}$ & $5.3 \mathrm{ab}$ & $39 \mathrm{ab}$ & $20 \mathrm{ab}$ & $1164 \mathrm{ac}$ & $3.5 \mathrm{a}$ & $2.3 \mathrm{a}$ \\
\hline VA & & $\mathrm{C} 2$ & $11.3 \mathrm{~b}$ & $3.5 \mathrm{a}$ & $6.5 \mathrm{ab}$ & $1.5 \mathrm{a}$ & $12.2 \mathrm{~b}$ & $6.2 \mathrm{~b}$ & $44 \mathrm{ab}$ & $22 \mathrm{ab}$ & $1220 \mathrm{c}$ & $3.5 \mathrm{a}$ & $2.8 \mathrm{a}$ \\
\hline VA & & $\mathrm{C} 3$ & $10.5 \mathrm{ab}$ & $3.1 \mathrm{a}$ & $6.5 \mathrm{ab}$ & $1.5 \mathrm{a}$ & $10.6 \mathrm{ab}$ & $5.1 \mathrm{ab}$ & $39 \mathrm{ab}$ & $19 \mathrm{ab}$ & $1191 \mathrm{c}$ & $3.7 \mathrm{a}$ & $2.8 \mathrm{a}$ \\
\hline VA & & $\mathrm{C} 4$ & $11.2 \mathrm{ab}$ & $3.2 \mathrm{a}$ & $7.1 \mathrm{~b}$ & $1.9 \mathrm{~b}$ & $11.7 \mathrm{~b}$ & $5.7 \mathrm{ab}$ & $45 \mathrm{~b}$ & $23 \mathrm{~b}$ & $1216 \mathrm{c}$ & $3.5 \mathrm{a}$ & $2.6 \mathrm{a}$ \\
\hline VA & & MP & $9.5 \mathrm{a}$ & $3.3 \mathrm{a}$ & $5.9 \mathrm{a}$ & $1.7 \mathrm{ab}$ & $8.5 \mathrm{a}$ & $4.6 \mathrm{a}$ & $32 \mathrm{a}$ & $16 \mathrm{a}$ & $895 \mathrm{~b}$ & $3.4 \mathrm{a}$ & $2.4 \mathrm{a}$ \\
\hline VA & & $\mathrm{OP}$ & $9.4 \mathrm{a}$ & $3.5 \mathrm{a}$ & $5.8 \mathrm{a}$ & $1.7 \mathrm{ab}$ & $8.5 \mathrm{a}$ & $4.8 \mathrm{a}$ & $31 \mathrm{a}$ & $16 \mathrm{a}$ & 1039 a & $3.7 \mathrm{a}$ & $2.8 \mathrm{a}$ \\
\hline $\mathrm{NC}$ & $\begin{array}{l}\text { Genetic } \\
\text { entry }\end{array}$ & $\mathrm{C} 1$ & $9.8 \mathrm{ab}$ & $3.3 \mathrm{a}$ & $5.9 \mathrm{a}$ & $1.6 \mathrm{a}$ & $8.5 \mathrm{ab}$ & $4.6 \mathrm{a}$ & $31 \mathrm{ab}$ & $16 \mathrm{ab}$ & $1104 \mathrm{a}$ & $3.9 \mathrm{a}$ & $2.9 \mathrm{a}$ \\
\hline $\mathrm{NC}$ & & $\mathrm{C} 2$ & $10.6 \mathrm{~b}$ & $3.7 \mathrm{ac}$ & $6.3 \mathrm{a}$ & $1.9 \mathrm{~b}$ & $10.4 \mathrm{~b}$ & $5.6 \mathrm{a}$ & $37 \mathrm{ab}$ & $20 \mathrm{~b}$ & $1181 \mathrm{a}$ & $3.6 \mathrm{a}$ & $3.2 \mathrm{a}$ \\
\hline $\mathrm{NC}$ & & $\mathrm{C} 3$ & $9.1 \mathrm{a}$ & $3.1 \mathrm{a}$ & $5.8 \mathrm{a}$ & $1.6 \mathrm{ab}$ & $7.9 \mathrm{ab}$ & $4.3 \mathrm{a}$ & $29 \mathrm{ab}$ & $15 \mathrm{ab}$ & $1162 \mathrm{a}$ & $3.1 \mathrm{a}$ & $2.4 \mathrm{a}$ \\
\hline NC & & $\mathrm{C} 4$ & $9.4 \mathrm{ab}$ & $3.3 \mathrm{a}$ & $5.9 \mathrm{a}$ & $1.7 \mathrm{ab}$ & $8.1 \mathrm{ab}$ & $4.5 \mathrm{a}$ & $29 \mathrm{ab}$ & $15 \mathrm{ab}$ & $1154 \mathrm{a}$ & $3.7 \mathrm{a}$ & $2.4 \mathrm{a}$ \\
\hline $\mathrm{NC}$ & & MP & $10.2 \mathrm{ab}$ & $3.6 \mathrm{ac}$ & $6.3 \mathrm{a}$ & $1.9 \mathrm{ab}$ & $7.8 \mathrm{ab}$ & $4.3 \mathrm{a}$ & $28 \mathrm{ab}$ & $15 \mathrm{ab}$ & $951 \mathrm{~b}$ & $3.7 \mathrm{a}$ & $2.8 \mathrm{a}$ \\
\hline $\mathrm{NC}$ & & $\mathrm{OP}$ & $9.1 \mathrm{a}$ & $4.0 \mathrm{bc}$ & $5.6 \mathrm{a}$ & $1.8 \mathrm{ab}$ & $5.7 \mathrm{a}$ & $4.1 \mathrm{a}$ & $20 \mathrm{a}$ & $11 \mathrm{a}$ & 915 b & $3.9 \mathrm{a}$ & $2.6 \mathrm{a}$ \\
\hline $\mathrm{BR}$ & $\begin{array}{l}\text { Genetic } \\
\text { entry }\end{array}$ & $\mathrm{C} 1$ & $17.2 \mathrm{ac}$ & $3.4 \mathrm{a}$ & $8.3 \mathrm{a}$ & $0.9 \mathrm{a}$ & $26.9 \mathrm{a}$ & $9.0 \mathrm{a}$ & $106 \mathrm{ab}$ & $40 \mathrm{ab}$ & $1211 \mathrm{a}$ & $5.7 \mathrm{a}$ & $4.9 \mathrm{a}$ \\
\hline $\mathrm{BR}$ & & $\mathrm{C} 2$ & $17.2 \mathrm{ac}$ & $3.3 \mathrm{a}$ & $8.6 \mathrm{a}$ & $1.4 \mathrm{bc}$ & $26.0 \mathrm{ac}$ & $8.8 \mathrm{a}$ & $103 \mathrm{ab}$ & $44 \mathrm{ab}$ & $1236 \mathrm{a}$ & $6.1 \mathrm{a}$ & $5.7 \mathrm{ac}$ \\
\hline $\mathrm{BR}$ & & C3 & $15.9 \mathrm{ab}$ & $3.0 \mathrm{a}$ & $8.4 \mathrm{a}$ & $1.1 \mathrm{ac}$ & $22.7 \mathrm{ac}$ & $7.6 \mathrm{a}$ & $92 \mathrm{ab}$ & $36 \mathrm{ab}$ & $1219 \mathrm{a}$ & $5.8 \mathrm{a}$ & $5.4 \mathrm{ac}$ \\
\hline $\mathrm{BR}$ & & $\mathrm{C} 4$ & $14.9 \mathrm{~b}$ & $3.0 \mathrm{a}$ & $7.9 \mathrm{a}$ & $1.2 \mathrm{ac}$ & $20.6 \mathrm{bc}$ & $7.2 \mathrm{a}$ & $81 \mathrm{a}$ & $33 \mathrm{~b}$ & $1233 \mathrm{a}$ & $6.7 \mathrm{a}$ & $6.7 \mathrm{bc}$ \\
\hline $\mathrm{BR}$ & & MP & $16.5 \mathrm{ac}$ & $3.1 \mathrm{a}$ & $8.5 \mathrm{a}$ & $1.2 \mathrm{bc}$ & $24.5 \mathrm{ac}$ & $7.9 \mathrm{a}$ & $100 \mathrm{ab}$ & $39 \mathrm{ab}$ & 1189 a & $5.8 \mathrm{a}$ & $5.8 \mathrm{ac}$ \\
\hline $\mathrm{BR}$ & & $\mathrm{OP}$ & $17.4 \mathrm{c}$ & $3.3 \mathrm{a}$ & $8.8 \mathrm{a}$ & $1.3 \mathrm{bc}$ & $27.7 \mathrm{a}$ & $9.2 \mathrm{a}$ & $117 \mathrm{~b}$ & $47 \mathrm{a}$ & $1228 \mathrm{a}$ & $6.7 \mathrm{a}$ & $6.6 \mathrm{bc}$ \\
\hline
\end{tabular}


Table 4

Parameter estimates for significant terms in the light use efficiency equation where I is absorbed photosynthetically active radiation, $\mathrm{G}$ is genetic entry (clones 1-4 (C1-C4), mass control-pollinated (MP), open pollinated (OP)), D is density $\left(618,1236,1854\right.$ trees ha ${ }^{-1}$ ) and * denotes an interaction. These equations were used to generate regression lines in Fig. 2.

\begin{tabular}{ll}
\hline Light use efficiency & \\
\hline Variable & Parameter estimate \\
\hline Intercept & 6.7 \\
I & 0.0222 \\
G-C1 & 29.1 \\
G-C2 & 14.1 \\
G-C3 & 39.5 \\
G-C4 & 55.0 \\
G-MP & 21.4 \\
G-OP & 0 \\
D-618 & -19.3 \\
D-1236 & -9.3 \\
D-1854 & 0 \\
I $^{*}$ G-C1 & -0.0148 \\
I*G-C2 & -0.0077 \\
I*G-C3 & -0.0226 \\
I*G-C4 & -0.0307 \\
I $^{*}$ G-MP & -0.0115 \\
I*G-OP $^{*}$. & 0 \\
\hline
\end{tabular}

number of trees per hectare increased the volume growth per unit of absorbed light (Fig. 2a and Table 4). This effect was likely a result of large crowns produced in low density stands relative to high density stands. Yáñez et al. (2015) measured crowns on the VA and NC sites and found that low stand density increased crown width $12 \%$ and live crown length $20 \%$. In this case, fixed carbon was apparently used to produce more and longer branches rather than stems. Kim et al. (2011) found overestimation of total absorbed light in low density stands (100 trees ha ${ }^{-1}$ ) regardless of leaf area. Our lowest density was planted at 618 trees ha $^{-1}$ and at the time of measurements, plots had at least 500 trees ha $^{-1}$. At 500 trees ha $^{-1}$, their model showed an $18 \%$ overestimation of absorbed light. If we overestimated absorbed light in the 618 trees ha $^{-1}$ treatment by $18 \%$, the regression line in Fig. $2 \mathrm{a}$ for this treatment would still be below the 1236 trees ha $^{-1}$ regression line indicating that it would still be possible for us to detect a significant density effect. Genotype effects produced an interesting pattern. As the amount of absorbed light increased, four genotypes (C1, C2, MP and OP) increased their volume growth per unit of light absorbed, one genotype (C3) had about the same volume per unit of light absorbed and one genotype (C4) decreased volume growth as absorbed light increased. The genotypes were selected to represent different crown ideotypes where C1 and C3 were narrow crown 'crop' ideotypes and C2 and C4 were broad crown 'competition' ideotypes. The MP and OP families were not specifically assessed for ideotype prior to study installation but were generally intermediate in crown size through age 4 at the VA and NC sites (Yáñez et al., 2015). The crop ideotypes are thought to grow well without competing with adjacent trees whereas the competition ideotypes aggressively competes for resources (Martin et al., 2001). The crown structure and competitive preference of the genotypes may have influenced the observed differences in LUE similar to the differences in LUE that Dallatea and Jokela (1991) attributed to crown structure in their examination of P. taeda and Pinus elliottii Engelm. However, why C3 and C4 did not increase volume growth with increasing absorbed light needs to be determined.

We rejected our third hypothesis because site did affect the cumulative volume and cumulative degree hour relationship (Fig. 3b). Tree growth is well correlated with temperature where elevated temperatures result in more growth (e.g. (Nedlo et al., 2009; Way and Oren, 2010)) and our results generally support these findings. Clearly, it was

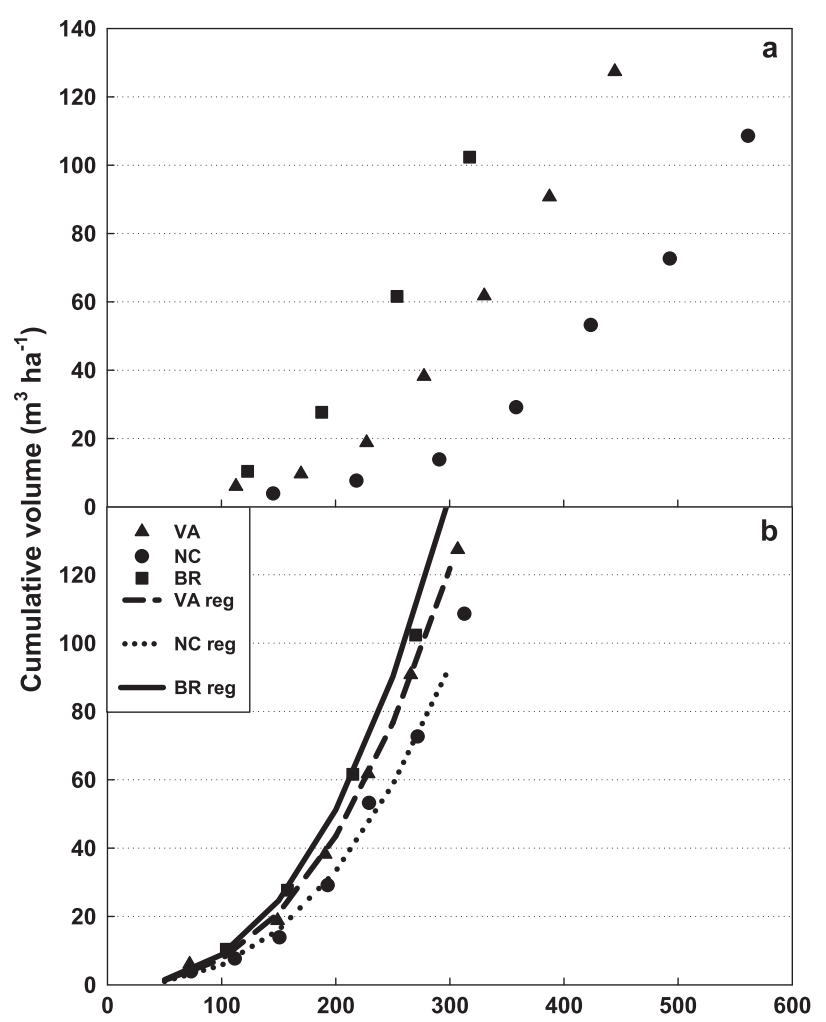

Cumulative degree hours $\left(>5^{\circ} \mathrm{C}\right)$ where ambient temperature is between 5 and $38^{\circ} \mathrm{C}$ and PAR $>0$, if nighttime temperature $<0^{\circ} \mathrm{C}$ no hours are counted the next day $(x 1000)$

Fig. 3. Cumulative volume and cumulative degree hours $\left(>5^{\circ} \mathrm{C}\right)$ where ambient temperature was between 5 and $38^{\circ} \mathrm{C}$, photosynthetically active radiation (PAR) was greater than zero (daytime) and if nighttime temperatures were below $0{ }^{\circ} \mathrm{C}$ no hours are counted the next day for three sites (Virginia (VA), North Carolina (NC) and Brazil (BR)) where the same Pinus taeda genetic entries were planted at three initial densities (a). In Panel b cumulative degree hours were estimated as in Panel a and included an adjustment for vapor pressure deficit (VPD) where hours when VPD exceeded $1.5 \mathrm{kPa}$ were not included. Regression lines for each sites are shown. Each point is a site mean.

warmer at the NC site (Table 1 and Fig. 1) and when examining only degree hours and accounting for potential loss of growth from cold temperatures, the NC site had considerably more degrees hours than the other sites. However, the site ranking of volume growth per unit of cumulative degree hours was $\mathrm{BR}>\mathrm{VA}>\mathrm{NC}$ (Fig. 3a). When including VPD, which helps eliminate degree hours where the temperatures are so warm that there is a detrimental effect on growth, the degree hours for the three site are much closer to each other but there is still a site effect where site ranking of volume growth per unit of cumulative degree hours was $\mathrm{BR}>\mathrm{VA}>\mathrm{NC}$. These results indicate that whereas more favorable weather may play a part in explaining the better growth observed in exotic plantations, there may be something else that contributes to the better exotic growth and thus would account for the site differences in volume growth per unit degree hour.

Alternatively, more favorable weather may explain the better growth observed when $P$. taeda was planted as an exotic but we did not completely filter for environmental conditions in this analysis to determine the full extent of environmental conditions and their effect on growth. The weather at the VA site is likely less favorable to growth than at the NC site while the weather at the BR site is more favorable than at the NC site. The VA site has similar rainfall patterns and amounts as the NC site but experiences colder temperatures in the winter (Fig. 1). The BR site has more moderate temperatures year round, temperature rarely goes below $0{ }^{\circ} \mathrm{C}$ or exceeds $27^{\circ} \mathrm{C}$. The minimum temperature for photosynthesis to occur in $P$. taeda is about 
$5{ }^{\circ} \mathrm{C}$ (Ellsworth, 2000) and the BR site likely experiences temperatures greater than that for most days year round. Cold nighttime temperatures (below $0{ }^{\circ} \mathrm{C}$ ) reduce leaf conductance (and imply a reduction in net photosynthesis) the following day regardless of environmental conditions on the following day (Teskey et al., 1987). Temperatures this low are regular events in the winter at the VA and NC sites. At the other extreme, temperatures in the summer can exceed $40{ }^{\circ} \mathrm{C}$ at the NC site and the mean monthly maximum for mid-summer (July) is $35.4^{\circ} \mathrm{C}$. In modeling work, Teskey et al. (1987) showed that when precipitation and light were held at optimum levels, high temperature in the summer could reduce productivity in $P$. taeda up to $80 \%$. Associated with high summer temperatures are conditions where VPD exceeding $1.5 \mathrm{kPa}$ have been shown to reduce $P$. taeda growth (Tang et al., 1999). Our analysis attempted to account for all of these factors by only counting degree hours between 5 and $38^{\circ} \mathrm{C}$, eliminating degree hours on days following below $0{ }^{\circ} \mathrm{C}$ nighttime temperatures and eliminating hours when VPD exceeded $1.5 \mathrm{kPa}$. Other factors that we did not include were respiration effects and the potential for extreme events to influence growth. Respiration increases with increasing temperature (Maier, 2001), which could reduce the carbon available for stem growth with the generally higher temperature at the NC site. Similarly, whereas the average annual minimum temperature at the BR site was higher than the other sites, the growing season minimum temperatures at the BR site were lower than those at the VA and NC site (Fig. 2c) and this could cause less respiratory carbon loss during the growing season. However, respiratory losses associated with higher temperatures will likely be mitigated because respiration may acclimate more strongly to higher temperatures than photosynthesis does (Way and Oren, 2010). Models using extreme climatic events may account for growth differences better than models only using mean values (Sangines de Carcer et al., 2017). The NC site has experienced extreme events compared to the other sites. During the first few years of growth, the site flooded seasonally, flooding was evident well into the growing season, and even though the trees were planted on beds that remained dry this may have had an effect on root development. More recently, the NC site experienced successive years with ice storms that did considerable damage breaking branches and the tops of trees. Clearly, there are differences in the weather at these sites that may play a part in the differences in the growth per unit degree hour that we were unable to capture in this analysis. A more detailed modeling effort (e.g. (Campoe et al., 2013; Watt et al., 2014) will be required to better determine the magnitude of the weather effect; the sites in this study will provide the opportunity to calibrate a model to better examine this hypothesis.

We identified site related growth differences at three sites where the same genetic material was planted in native and exotic locales. Differences in light environment (greater sunlight intensity (Wallinger, 2002) or higher solar radiation intensities (Harms et al., 1994)) have been proposed to explain the difference observed in native and exotic plantations. We examined this idea by testing for site differences in LUE but did not detect any site differences for stem volume growth. There are additional hypotheses proposed to explain this phenomenon including a longer growing season, (Wallinger, 2002), a more favorable climate permitting year-round growth (Samuelson et al., 2010), and evaporative demand (Waring et al., 2008). To examine these ideas, we developed a heat sum approach to estimate degree hours where the daytime temperature was between 5 and $38^{\circ} \mathrm{C}$, hours where vapor pressure deficit exceeded $1.5 \mathrm{kPa}$ were excluded, as were days following nights where nighttime temperatures were less than $0^{\circ} \mathrm{C}$. This analysis showed greater growth per unit of degree hours for the BR site indicating that something other than these factors was causing the observed difference in growth. However, additional factors including respiration and extreme climatic conditions may also contribute to the differences in growth per unit degree hour and including these differences in the analysis would require a more detailed modeling effort to examine. The sites used in this study are ideally suited to continue testing additional hypotheses to explain the different growth between native and exotic $P$. taeda plantations because they have the same genotypes at all sites and consequently eliminate differences in genetics as a potential explanation for observed growth differences.

\section{Acknowledgements}

We appreciate support from the Forest Productivity Cooperative and members for their role in the establishment and management of the trials central to this publication. We gratefully acknowledge the support provided by the National Science Foundation Center for Advanced Forest Systems, the Department of Forest Resources and Environmental Conservation at Virginia Polytechnic Institute and State University, the Departamento de Silvicultura, Facultad de Ciencias Forestales, Universidad de Concepción, the Department of Forestry and Environmental Resources at North Carolina State University and the Federal University of Santa Catarina. Funding for this work was provided in part by the Virginia Agricultural Experiment Station and the McIntire-Stennis Program of the National Institute of Food and Agriculture, U.S. Department of Agriculture. The use of trade names in this paper does not imply endorsement by the associated agencies of the products named nor criticism of similar ones not mentioned. We are grateful for Arborgen for supplying the genetic material, for the assistance of K. Peer and C. Sawyer at The Reynolds Homestead, H.C. Rohr at the North Carolina Forest Service's Bladen Lakes State Forest and the personnel at Valor Florestal in the installation and ongoing maintenance of the study sites.

\section{References}

Albaugh, T.J., Albaugh, J.M., Fox, T.R., Allen, H.L., Rubilar, R.A., Trichet, P., Loustau, D., Linder, S., 2016. Tamm review: light use efficiency and carbon storage in nutrient and water experiments on major forest plantation species. For. Ecol. Manage. 376, 333-342.

Albaugh, T.J., Allen, H.L., Stape, J.L., Fox, T.R., Rubilar, R.A., Carlson, C.A., Pezzutti, R., 2010. Leaf area duration in natural range and exotic Pinus taeda. Can. J. For. Res. 40, 224-234.

Antony, F., Schimleck, L.R., Jordan,L., Hornsby,B., Dahlen,J., Daniels, R.F., Clark, A., III, Apiolaza, L.A., Huber, D.A., 2014. Growth and wood properties of genetically improved loblolly pine: propagation type comparison and genetic parameters. Can.J. For.Res., 44 (3), 263-272.

Barrichelo, L.E.G., Kageyama, P.Y., Speltz, R.M., Bonish, H.J., Brito, J.O., Ferreira, M., 1977. Estudos de procedências de Pinus taeda visando seu aproveitamento industrial. Instituto de Pesquisas e Estudos Florestais 15, 1-14.

Baskerville, G.L., 1972. Use of logarithmic regression in the estimation of plant biomass. Can. J. For. Res. 2 (1), 49-53.

Campoe, O.C., Stape, J.L., Albaugh, T.J., Allen, H.L., Fox, T.R., Rubilar, R.A., Binkley, D. 2013. Fertilization and irrigation effects on tree level aboveground net primary production, light interception and light use efficiency in a loblolly pine plantation. For. Ecol. Manage. 288, 43-48.

Cannell, M.G.R., 1989a. Light interception, light use efficiency and assimilate partitioning in poplar and willow stands. In: Pereira, J.S., Landsberg, J.J. (Eds.), Biomass production by fast-growing trees. Kluwer Academic Publishers, The Netherlands, pp. $1-12$.

Cannell, M.G.R., 1989b. Physiological basis of wood production: a review. Scand. J. For. Res. 4, 459-490.

Cregg, B.M., Teskey, R.O., Dougherty, P.M., 1993. Effect of shade stress on growth, morphology, and carbon dynamics of loblolly pine branches. Trees: Structure and Function, 7 (4), 208-213.

CRONOS. 2015. State Climate Office of North Carolina CRONOS [Internet database on climate in the southeast US]. NC State University. http://climate.ncsu.edu/cronos/. North Carolina State University (January 7, 2016).

Cubbage, F., MacDonagh, P., Júnior, J.S., Rubilar, R.A., Donoso, P., Ferreira, A., Hoeflich, V., Olmos, V.M., Ferreira, G., Balmelli, G., Siry, J., Báez, M.N., Alvarez, J., 2007. Timber investment returns for selected plantations and native forests in South America and the Southern United States. New Forests, 33, 237-255.

Dallatea, F., Jokela, E.J., 1991. Needlefall, canopy light interception, and productivity of young intensively managed slash and loblolly-pine stands. For. Sci. 37 (5), 1298-1313.

Ellsworth, D.S., 2000. Seasonal $\mathrm{CO}_{2}$ assimilation and stomatal limitations in a Pinus taeda canopy. Tree Physiol. 20, 435-445.

Farnum, P., Timmis, R., Kulp, J.L., 1983. Biotechnology of forest yield. Science 219 (4585), 694-702.

Fox, T.R., Jokela, E.J., Allen, H.L., 2007. The development of pine plantation silviculture in the southern United States. J. For. 105 (5), 337-347.

Goncalves, J.L., Alvares, C.A., Higa, A.R., Silva, L.D., Alfenas, A.C., Stahl, J., Ferraz, S.F., Lima, W.P., Brancalion, P.H., Hubner, A., Bouillet, J.P., Laclau, J.P., Nouvellon, Y., Epron, D., 2013. Integrating genetic and silvicultural strategies to minimize abiotic 
and biotic constraints in Brazilian eucalypt plantations. For. Ecol. Manage. 301, 6-27. Harms, W.R., De Bell, D.S., Whitesell, C.D., 1994. Stand and tree characteristics and stockability in Pinus taeda plantations in Hawaii and South Carolina. Can. J. For. Res. 24, 511-521.

Harms, W.R., Whitesell, C.D., DeBell, D.S., 2000. Growth and development of loblolly pine in a spacing trial planted in Hawaii. For. Ecol. Manage. 126, 13-24.

INMET. 2017. Instituto Nacional de Meteorologia. Instituto Nacional de Meteorologia. $<$ http://www.inmet.gov.br/portal/index.php?r= estacoes/estacoesAutomaticas > (September 18, 2017).

Kim, H.S., Palmroth, S., Thérézien, M., Stenberg, P.T., Oren, R., 2011. Analysis of the sensitivity of absorbed light and incident light profile to various canopy architecture and stand conditions. Tree Physiol. 31, 30-47.

Knohl, A., Baldocchi, D.D., 2008. Effects of diffuse radiation on canopy gas exchange processes in a forest ecosystem. J. Geophys. Res. 113, 1-17.

Landsberg, J.J., 1986. Physiological Ecology of Forest Production. Academic Press, London.

Leite, H.G., Nogueira, G.S., Moreira, A.M., 2006. Efeito do espaçamento e da idade sobre variáveis de povoamentos de Pinus taeda L. Revista Arvore 30 (4), 603-612.

Linder, S., 1985. Potential and actual production in Australian forest stands. In: Landsberg, J.J., Parsons, W. (Eds.), Research for forest management. CSIRO, Melbourne, pp. 11-35.

Littell, R.C., Milliken, G.A., Stroup, W.W., Wolfinger, R.D., Schabenberger, O., 2006. SAS for mixed models. SAS Publishing, Cary, NC.

Maier, C.A., 2001. Stem growth and respiration in loblolly pine plantations differing in soil resource availability. Tree Physiol. 21, 1183-1193.

Martin, T.A., Johnsen, K.H., White, T.L., 2001. Ideotype development in southern pines: rationale and strategies for overcoming scale-related obstacles. For. Sci. 47 (1), $21-28$.

Martin, T.A., Jokela, E.J., 2004. Stand development and production dynamics of loblolly pine under a range of cultural treatments in north-central Florida USA. For. Ecol. Manage. 192 (1), 39-58.

McMaster, G.S., Wilhelm, W.W., 1997. Growing degree-days: one equation, two interpretations. Agric. For. Meteorol. 87, 291-300.

Monteith, J.L., 1977. Climate and the efficiency of crop production in Britain. Phil. Trans. R. Soc. Lond. B 281, 277-294.

Nedlo, J.E., Martin, T.A., Vose, J.M., Teskey, R.O., 2009. Growing season temperature limit growth of loblolly pine (Pinus taeda L.) seedlings across a wide geographic transect. Trees: Structure and Function, 23, 751-759.

Pezzutti, R. 2011. Efeitos biologicos e economicos de tratamentos silviculturais em plantios de Pinus taeda L. no nordeste Argentino. Ph.D., Universidade Federal de Santa Maria.

Piepho, H.P., Buchse, A., Emrich, K., 2003. A hitchhiker's guide to mixed models for randomized experiments. J. Agron. Crop Sci. 189 (5), 310-322.

Prestemon, J.P., Abt, R.C., 2002. Timber products supply and demand. In: Wear, D.N., Greis, J.G. (Eds.), Southern Forest Resource Assessment. SRS-GTR-53 Ed., USDA Forest Service, Asheville, NC, pp. 299-325.

Sampson, D.A., Allen, H.L., 1995. Direct and indirect estimates of leaf area index (LAI) for lodgepole and loblolly pine stands. Trees: Structure and Function, 9, 119-122.

Samuelson, L.J., Eberhardt, T.L., Butnor, J., Stokes, T.A., Johnsen, K.H., 2010. Maximum growth potential in loblolly pine: results from a 47-year-old spacing study in Hawaii. Can. J. For. Res. 10, 1914-1929.
Sangines de Carcer, P., Vitasse, Y., Penuelas, J., Jassey, V.E.J., Buttler, A., Signarbieux, C., 2017. Vapor-pressure deficit and extreme climatic variables limit tree growth. Global Change Biol. 2017, 1-15.

SAS-Institute. 2002. SAS Version 9.1 TS. SAS Institute, Inc: Cary, NC.

Schabenberger, O. 2013. SAS Code for some advanced experimental designs. UC Regents. < http://people.math.carleton.ca/ smills/2016-17/STAT5505/SAS\%20Code \%20for\%20Some\%20Advanced\%20Experimental\%20Designs.htm > . (December 13, 2017).

Spokas, K., Forcella, F., 2006. Estimating hourly incoming solar radiation from limited meteorological data. Weed Sci. 54, 182-189.

Sprugel, D.G., Hinckley, T.M., Schaap, W., 1991. The theory and practice of branch autonomy. Ann. Rev. Ecol. Syst. 22, 309-334.

Susaeta, A., Carter, D.R., Adams, D.C., 2014. Sustainability fo forest management under changing climatic conditions in the southern United States: adaptation strategies, economic rents and carbon sequestration. J. Env. Manage. 139, 80-87.

Tang, Z.M., Chambers, J.L., Barnett, J.P., 1999. Characterization of optimum physiological responses of field grown loblolly pine. In: Proceedings of the tenth biennial southern silvicultural research conference Gen. Tech. Rep. SRS-30.

Tasissa, G., Burkhart, H.E., Amateis, R.L., 1997. Volume and taper equations for thinned and unthinned loblolly pine trees in cutover, site-prepared plantations. South. J. Appl. For. 21 (3), 146-152.

Teskey, R.O., Bongarten, B.C., Cregg, B.M., Dougherty, P.M., Hennessey, T.C., 1987. Physiology and genetics of tree growth response to moisture and temperature stress: an examination of the characteristics of loblolly pine (Pinus taeda L.). Tree Physiol. 3 , 41-61.

Vickers, L.A., Fox, T.R., Stape, J.L., Albaugh, T.J., 2011. Silviculture of varietal loblolly pine plantations: Second year impacts of spacing and silvicultural treatments on varieties with differing crown ideotypes. J. Butnor (ed.). USDA Forest Service, Southern Research Station, Asheville, NC, pp. 361-365.

Vose, J.M., Allen, H.L., 1988. Leaf-area, stemwood growth, and nutrition relationships in loblolly-pine. For. Sci. 34 (3), 547-563.

Wallinger, R.S., 2002. Intensive forest management: Growing wood and preserving biodiversity in the U.S. South and Brazil. For.Oper.Rev. 4 (3), 5-11.

Waring, R.H., Landsberg, J.J., Linder, S., 2016. Tamm Review: Insights gained from light use and leaf growth efficiency indices. For. Ecol. Manage. 379, 232-242.

Waring, R.H., Nordmeyer, A., Whitehead, D., Hunt, J., Newton, M., Thomas, C., Irvine, J., 2008. Why is the productivity of Douglas-fir higher in New Zealand than in its native range in the Pacific Northwest, USA? For. Ecol. Manage. 255 (2008), 4040-4046.

Watt, M.S., Rubilar, R.A., Kimberley, M.O., Kriticos, D.J., Emhart, V.I., Mardones, O., Acevedo, M., Pincheira, M., Stape, J.L., Fox, T.R., 2014. Using seasonal measurement to inform ecophysiology: extracting cardinal growth temperatures for process-based growth models of five Eucalyptus species/crosses from simple field trials. N.Z. J. For. Sci. 44 (9), 1-11.

Way, D.A., Oren, R., 2010. Differential responses to changes in growth temperature between trees from different functional groups and biomes: a review and synthesis of data. Tree Physiol. 30, 669-688.

Yáñez, M.A., Fox, T.R., Seiler, J.R., 2015. Early responses of loblolly pine varieties and families to silvicultural intensity. For. Ecol. Manage. 356, 204-215.

Zhao, D., Kane, M.B., Teskey, R.O., Fox, T.R., Albaugh, T.J., Allen, H.L., Rubilar, R.A. 2016. Maximum response of loblolly pine plantations to silvicultural management in the southern United States. For. Ecol. Manage. 375, 105-111. 